\title{
CROATIAN FOREIGN POLICY: A SYSTEMIC LITERATURE REVIEW
}

\section{HRVATSKA VANJSKA POLITIKA: SISTEMSKI PREGLED LITERATURE}

\author{
Amer Kurtović \\ amer.kurtovic@ibu.edu.ba \\ Sanel Safić \\ sanel.safic@stu.ibu.edu.ba
}

\begin{abstract}
This paper systemically analyzes the scholarly literature on Croatian foreign policy in general and in specific towards its eastern neighbors - Bosnia and Herzegovina, Montenegro, and Serbia - and categorizes them according to the selected theoretical framework, data collection, and data analysis methods used, and results generated. There are five discernible streams of academic study and scholarly analysis of Croatian foreign policy: those leveraging a) traditional theoretical frameworks and those leveraging b) less traditional theoretical frameworks, both usually taking a macro-approach, those focusing on c) the policy process and the shift of power from the head of state to the head of government, d) those thematizing Croatia's bilateral relations with individual Western Balkans states as a niche foreign policy, and e) prospective-orientated studies seeking to map a future course for Croatian foreign policy, post-EU accession. The findings point to a noticeable lack of constructivist and especially discursive studies analyzing Croatian foreign policy, generally and specifically toward its eastern neighbors.
\end{abstract}

Sažetak: Ovaj rad sistematično analizira naučnu literaturu o hrvatskoj vanjskoj politici općenito i naročito prema istočnim susjedima - Bosna i Hercegovina, Crna Gora i Srbija - te je kategorizira po korištenom teoretskom okviru, metodama prikupljanja i analize podataka te rezultatima. Postoji pet okvirnih pristupa izučavanju Hrvatske vanjske politike: oni koji koriste a) tradicionalne teoretske okvire $i$ b) oni koriste manje tradicionalne okvire, a obje kategorije literature inače koriste makro-nivo analize, c) oni koji izučavaju procese $i$ prenos ovlasti za vanjsku politiku od šefa države prema šefa vlade, d) oni koji tematiziraju hrvatsku vanjsku politiku prema pojedinim zapadnobalkanskim državama kao niša vanjske politike, te d) prospektivno-orijentisane studije koje teže mapirati budući pravac hrvatske vanjske politike. Nalazi pokazuju nedostatak konstruktivističih i naročito diskusrsnih

Keywords: Croatia, EU, Systemic Literature Review, Western Balkans

JEL Classification: F50

Article History

Submitted:30/12/2021

Accepted:31/12/2021

Ključne riječi: Hrvatska, EU, sistemski pregled literature, Zapadni Balkan

Historija članka

Dostavljen: 30.12.2021

Prihvaćen: 31.12 .2021 
studija koji analiziraju hrvatsku vanjsku politiku, općenito $i$

naročito prema istočnim susjedima.

\section{INTRODUCTION}

The scholarly literature on Croatia's foreign policy is rather extensive, spanning the period from its independence onward. Most literature focuses on the period between 2000 when Croatia's international isolation ended, and 2013 when Croatia acceded into the European Union. Although most published works focus predominantly on Croatia's single-goal-oriented foreign policy, they also include contributions about relations with neighboring states and some are even dedicated to Croatia's regional foreign policies. In addition, much literature, especially by Croatian authors, is both analytical and prescriptive in that it offers an analysis of past and current foreign policies and recommends future courses of action to be taken. Few works, however, use constructivist and especially discursive approaches to analyze Croatia's foreign policy and the (mis)match between foreign policy actions and foreign policy discourses while a few also briefly mention the (mis)match between the president's and the prime minister's foreign policy preferences, actions, and discourses.

This work is a systemic literature review that gathers the scholarly literature on Croatian foreign policy to synthesize their main elements, critically evaluate the body of literature as a whole, and identify main research gaps. This literature review is divided into five main chapters, each of which corresponds to a key finding of the review and a main strand of the literature: the first section reviews traditional perspectives on Croatia's foreign policy; the second section other, which I heuristically label "less traditional," perspectives on Croatia's foreign policy; the third section the foreign policy-making processes; the fourth section the bilateral relations between Croatia and its three immediate neighbors to the east from 2000 onward; and the fifth section the projections of and opportunities for Croatia's foreign policy in the future, especially in light of Croatia's then-recent EU membership.

Two databases were used for identifying publications on the topic, one of which is local and specializes in local topics: Google Scholar and track.srce.hr. In addition, publications were mined from conference proceedings, policy papers, and reference lists of already identified publications. Essentially no filters were used to include the largest amount of publications possible. These were then coded according to the theoretical framework selected, data collection and data analysis methods used, and results generated. These findings are systemically presented in five thematic categories.

\section{TRADITIONAL PERSPECTIVES ON CROATIA'S FOREIGN POLICY}

All authors ${ }^{1}$ who write about Croatia's foreign policy identify three distinct periods of Croatian foreign policy and characterize it as single-goal oriented; some ${ }^{2}$ discuss a fourth period that is

\footnotetext{
${ }^{1}$ Prominent ones include: Grubiša, D. Jakovina, T., Jović, D., and Šelo Šabić, S.

${ }^{2}$ They include: Jakovina, T., Jović, D., Rešić, A., and Šelo Šabić, S.
} 
forming and propose a regional orientation as Croatia's foreign policy niche. The three periods of foreign policy identified are: seeking and gaining international recognition of Croatia, gaining effective control over its entire territory, and accession into the North Atlantic Treaty Organization and the European Union (Jović, 2011). They also subjugate or attribute other visible foreign policies to its single, overarching goal in the given context: support of Croats in Bosnia and Herzegovina in the early 1990s to its endeavor to gain control over its internationally recognized territory and regional relations from 2000 onward to its quest for EU accession, i.e., EU conditionality of regional cooperation as a criterion for accession (ibid.).

In his 2011 work on the prospects of Croatian foreign policy immediately before the country accedes to the European Union ${ }^{3}$, Dejan Jović explains the relationship between Croatia's aspirations to join the European Union and its regional policy: "all other aspects of foreign policy, as well as many other aspects of other public policies, were subjugated to [the goal of EU accession]. Croatian regional policy, which achieved significant successes since 2003, was also subjugated to that goal" (p. 13). The departure from Tuđman-era foreign policies, which has consolidated the Croatian state but at the same time led to "[isolation] from the rest of Europe and [alienation] from much of the rest of the region" (Grubiša, p. 117), was luculently marked by the Zagreb Summit in 2000. Croatia's acceptance of regional initiatives at the Zagreb Summit where the European Union stressed its importance "as crucial for post-conflict stabilization, including the transfer of European norms" (Šelo Šabić, p. 79), however, did not come without a caveat:

Even though Croatia accepts regional cooperation and is prepared for continuous involvement in the creation of conditions for the establishment of quality relations between states, as a need and an expression of its interest, too - "it does not want to become a captive of the region and thereby remain enclosed within its borders". Regional cooperation, in the view of the Croatian president, must not be an end in itself, but it must be just one of the steps in the "hopefully not too long road to the European Union." (Grubiša, p. 118)

Since traditional perspectives on Croatian foreign policy predominantly identify and describe the three periods of Croatian foreign policy - acquiring international recognition, regaining control over territory, and joining NATO and the EU - largely through realist and liberal prisms, it is necessary to explore and assess less traditional perspectives on Croatian foreign policy, some of which also offer analyses thereof.

\section{LESS TRADITIONAL PERSPECTIVES ON CROATIAN FOREIGN POLICY}

There are three major non-traditional perspectives on Croatian foreign policy present and identifiable in at least part of the literature on the topic: Croatia's perception of its place in the region and identity politics in international relations, a functionalist perspective on Serbo-

\footnotetext{
${ }^{3}$ Although Croatia acceded into the European Union on July 1, 2013 (source), accession negotiations finished on June 30, 2011 (source) and Croatia signed the accession treaty on December 9, 2011 (source). At the time the paper was published, Croatia's entry into the European Union was a question of when and not of if; thus, the author's comment ought to be considered in the light of Croatia's imminent accession to the European Union.
} 
Croatian cooperation in the early 2010s, and a perspective focusing on the power and role of personality in Croatian foreign policymaking. These three perspectives are non-traditional since they move past the division of Croatian foreign policy history into three distinct, single-goal phases.

As Senada Šelo Šabić notes, albeit only in an endnote, Croatia's reluctance in the early 2000s (decade) to partake in "regional cooperation [referred] only to cooperation with the countries of the Western Balkans" (p. 88), while it actively sought cooperation with Central and Eastern European states. This differentiation, even segregation, by Croatia of non-EU member-states at the time is indicative of a difficulty "accepting where Croatia is and which space it borders [and reconciling] that [Croatians and Croatian official circles] see [themselves] as on the edge of Middle Europe" (Jakovina, p. 89) but must readily participate in Western Balkan's regional initiatives as a result of the insistence of the international community. The authors dealing with this agreement that such a stance is primarily due to matters of identity: Croatians do not feel (Western) Balkan but "see[s] [themselves] as different from the region where [they are] located" (Jakovina, p. 89) and later evolved, under pressure from the international community, to "[insist] that it's the leader of the region" (p. 90). Croatia's perception of its role in the region further evolved after it concluded accession negotiations with the European Union in 2011: its Government declared that Croatia would seek to be "a connection between the region and the EU, to know better what is happening in the region and transfer that knowledge to Brussels in order to more clearly and more precisely understand possible problems, and to influence decision-making in order to bring about the best decisions" (Šelo Šabić, p. 18). Šelo Šabić posited that was to avoid being the European Union's external border for an extended period of time, since that would impact the Croatian national identity by "opening space for advocating past concepts: a frontier mentality, a bulwark of Christianity, and the last line of defense from the barbers from the east" (Šelo Šabič, p. 18). In addition, Croatia’s foreign policy, especially towards Serbia, largely depends on internal and historical factors due to the "recent past and still uncured memories of the war (1991-1995) and the fact that anti-Serbianism was always (and is still today) a focus point around which Croatian nationalism can consolidate and mobilize around the quickest" (Jović, p. 11). Allison Johnson in her bachelor's thesis concludes well:

As constructivism posits, the identity of Croatia is the main factor for explaining its foreign policy; therefore, Croatia's numerous identities all suggest different policy options. The way these four identities ${ }^{4}$ relate is relevant for understanding what could be a schizophrenic regional policy, sometimes complying with EU mandates and sometimes not. $(2014$, p. 8$)$

In addition to this focus on constructivist and identity-based foreign policy, two other strands of non-traditional perspectives on Croatian foreign policy are visible in the literature: a functionalist perspective and one that focuses on the power and role of personality. Jović (n.d.) used functionalism to analyze bilateral relations between Croatia and Serbia in the early period

\footnotetext{
${ }^{4}$ The four identities, as related to the 1991-1995 war are: "a heroic nation that courageously stood up to Serbian aggression, an innocent nation with a few bad war criminals, a Western nation that adheres to democratic values, and a Balkan nation with the expected criminal habit." (p. 8)
} 
of Ivo Josipović's presidency and late period of Boris Tadić's presidency and conclude that their joint initiatives were "a significant change in comparison to the 1990s (because the two presidents created a new discourse which included explicitly confronting crimes and wholeheartedly condemning them), as well as to the state of affairs after Croatia recognized Kosovo's independence" (p. 1). He also notes that such functional cooperation had the effects of allowing the two countries to cooperate in a wide variety of fields and to cooperate in efforts to "stabilize and democratize Bosnia and Herzegovina... in which the roles of Croatia and Serbia are especially important but secondary" (p. 7). Also related to this specific functionalist interpretation of Serbo-Croatian relations between the beginning of Josipović's and end of Tadić's presidential terms, in which their similarities and abilities to bond are emphasized at the expense of structural features (Jović, pp. 1-2), is the perspective emphasizing the power and role of personality. Accordingly, the power dynamics in Croatia's cohabitation executive significantly hinder the acceptance and execution of policies, rendering some actions "of a more symbolic, rather than a pragmatic importance" (Jović, p. 10). This pronounced cohabitation - a president from a political option which is in opposition - was one of the reasons the initial success of the Josipović-Tadić summits was short-lived; the other was Tadić's electoral failure in the Serbian presidential elections in 2012 and his subsequent replacement by a nationalistic figure. During the previous Croatian president's terms, "being 'more for Mesić' than for the prime ministers could mean that some of the open doors in the countries the president visited weren't used to prevent excess responsibility being 'assigned' to the wrong center of power" (Jakovina, p. 85). Lastly, the appointment of Vesna Pusić, "a long-time opposition politician with strong convictions, outspoken, and steadfast” (Šelo Šabič, p. 78), as foreign minister led to the center of foreign policymaking for the first time in Croatian history to shift from the president and the prime minister to the Ministry of Foreign Affairs.

The three non-traditional approaches to studying Croatian foreign policy are constructivism, functionalism, and the power of personality. Each brings a specific and valuable contribution to the study of Croatian foreign policy that allows further analysis thereof and, although less represented in the literature than more traditional perspectives, they deserve great attention as a starting point for further similar research.

\section{PROCESS OF FOREIGN POLICYMAKING IN CROATIA (SINCE 2000)}

Article 99 of the Constitution of the Republic of Croatia regulates foreign policy and delineates the responsibilities of the president and the government in foreign policymaking. The president and the government, represented and led by the prime minister, are constitutionally required to coordinate foreign policy efforts, and the former is tasked with representing the state while the latter is tasked with guiding, and through the Ministry of Foreign and European Affairs, executing foreign policy. This is a cohabitation system of governance in the executive branch leads to the president's foreign policies being "sometimes more symbolic, rather than pragmatic, importance" (Jović, p. 10). The Law on Foreign Affairs also defines processes within foreign policymaking, specifically about the Ministry of Foreign and European Affairs. 
It is, according to the relevant literature ${ }^{5}$, these three actors - the president, the prime minister, and the minister of foreign affairs - that have the most influence on foreign policymaking, each pole dominating the process during different periods. According to Šelo Šabić and Jović, there are three identifiable periods in which one of the three poles exerted significant influence over foreign policymaking in Croatia: Ivo Sanader "who concentrated more power in his hands, including foreign policy-making... [and whose foreign ministers'] positions depended on demonstrating loyalty of the prime minister" (Šelo Šabić, p. 78); Ivo Josipović at the beginning of his term who used his similarity to his Serbian counterpart to drive Croatian foreign policy (Jović); and Vesna Pusić's term as foreign minister when "she started energetically and ambitiously [placing] the Ministry [of Foreign and European Affairs] in the driving seat of foreign policymaking" (Šelo Šabić, p. 78).

Besides resting on constitutional and legal provisions and generalizations deduced from media reports or press statements, there is no systemic study of the processes whereby foreign policies are created and executed in Croatia. In addition, the available literature either does not explicitly presuppose a theoretical model upon which the studies in question are based or rests on largely traditional theories, such as realism, liberalism, and functionalism; however, no studies of Croatia's regional policy, i.e. its foreign policy towards its neighbors and especially immediate eastern neighbors, rest on explicit theoretical assumptions. Therefore, the existing literature is lacking a systemic study of Croatia's foreign policy toward its neighboring states that explicitly bases its methodology and results on a less traditional theory, especially one emphasizing mismatch between foreign policy actions and foreign policy discourses and the relations between the president, the prime minister, and the minister of foreign affairs in foreign policymaking.

\section{BILATERAL RELATIONS OF CROATIA WITH BOSNIA AND HERZEGOVINA, MONTENEGRO, AND SERBIA}

Since some aspects ${ }^{6}$ of Croatia's relations with its eastern neighbors were already discussed in the previous section in contexts of non-traditional perspectives on Croatian foreign policy and Croatia's regional policy, this section will focus on the more traditional approaches to studying the bilateral relations between Croatia and Bosnia and Herzegovina, Montenegro, and Serbia, therefore omitting those already discussed aspects. As such, it will focus largely on the structural features of the bilateral relationships. It will also include the other countries' policies toward Croatia as bilateral relations are necessarily bilateral, i.e. not one-way, and other countries' responses to Croatian policies create a dynamic bilateral relationship that provides greater analytic insight and provides greater explanatory power.

\footnotetext{
${ }^{5}$ Authors include: Johnson, A., Jović, D., and Rešić, A..

${ }^{6}$ They include: Croatia's regional policy as a precondition of EU accession; the role of the Other, and specifically Serbia, in the creation of the Croatian Self and its foreign and regional policies; bilateral issues Croatia had and has with neighbors; limited rapprochement with Serbia in the early 2010s; and Croatia's regional policy after concluding accession negotiations as a regional leader or a connection between the region and the European Union.
} 
Croatia's relations with Bosnia and Herzegovina are burdened by three main factors: the sizeable part of the population in Bosnia and Herzegovina who declare themselves as ethnic Croats and for whom Croatia is constitutionally required to protect (Šelo Šabić, p. 80), which the majority Bosniak population sees as illegitimate and which led to several instances of direct and indirect involvement of Croatia into the electoral and internal administrative politics of Bosnia and Herzegovina (Šelo Šabič, p. 17); the historic relations between the two countries, including Croatia's complicity in Herzeg-Bosnia's war crimes, its participation in the war in Bosnia and Herzegovina, and its role in the negotiation and signing of the Washington and Dayton Agreements (ibid., Jakovina, 2010), and myriad unresolved bilateral issues, such as the "economy, transport and the regime for people with dual citizenship [as well as] potentially sensitive disputes over small islands of Veliki and Mali Škoj or bordering over river Una in Hrvatska Kostajnica and BiH Kostajnica” (Rešić, p. 93). Relations, however, have been on an upward trend: Stjepan Mesić, Croatia's second president, choose Bosnia and Herzegovina as the destination of his first official state visit (Johnson, 2014); Ivica Račan and Ivo Sanader, the first two post-Tuđman prime ministers from opposite ideological specters, reduced relations with Croats in Bosnia and Herzegovina and cooperated with the ICTY by arresting and extraditing indicted war criminals (ibid.); and Ivo Josipović, Croatia's third president, in effect apologized for Croatia's role in the war in Bosnia and Herzegovina (ibid.); Jadranka Kosor, Sanader's successor from the same party, provided neighboring states with translated accession documents. This is in addition to Croatia's support for Bosnia and Herzegovina's membership in the European Union, albeit for the self-interested reason of fulfilling "the advantages of EU membership" (Samrdžija, p. 27), and "allow[ing] Bosnia and Herzegovina to continue using Ploče and establish[ing] necessary structures to allow the continued export of Bosnian goods into Croatia and the EU" (Johnson, p. 28). Because foreign policymaking in Bosnia and Herzegovina "is still dominated by a struggle between the three ethnic groups" (Huskić, p. 128), which results in the "foreign policy of Bosnia and Herzegovina [being] limited mostly to noncontentious issues around which a consensus can be built" (ibid.) and which is demonstrated by the fact that "Croatia has "almost different foreign policies when talking to Sarajevo or Banja Luka” (Rešič, p. 93-4), Bosnia and Herzegovina has rarely been able to have an equally effective foreign policy and partake equally or fully in Croatian-Bosnian and Herzegovinian relations.

Bilateral relations with Croatia are much simpler than those with Bosnia and Herzegovina since the only burden to their bilateral relations is those related to the publicity associated with a single border dispute which was largely solved using quite a diplomacy (Rešić, year) and the overcome legacy of Montenegrin troops' involvement in the bombardment of Dubrovnik (Vukičević, 2017). Relations between the two countries date back to 1997, when "external relations... were established as a part of the 'creeping independence' policy before Montenegro's independence” (Džankić, 2014, p. 183), which contributed to the development of frictionless relations between the two countries. Furthermore, Montenegro is the only state in the region that extensively utilizes Croatia's expertise, which was put at their disposal through the Ministry of Foreign and European Affairs' Center of Excellence, in European integration by signing "the Agreement on Euro-Atlantic Partnership with Croatia as a framework for the transfer of knowledge which Croatia gained during accession to Euro- 
Atlantic structures" (Šelo Šabić, p. 81). Montenegro's foreign policy aims, as enumerated by the constitution, confirmed by various documents, and reinforced by widespread public consensus, align with and mirror those of Croatia: integration into NATO and the EU (Johnson, year). Due to the similarities between the two states' internal structures (unitary with sizeable minorities) and foreign policy goals, as well as limited scope for disputes due to their short border and Montenegro's orientation toward multilateral relations as opposed to bilateral relations (Džankić, 2014), Croatia and Montenegro are natural partners or even allies. As Johnson (2014) notes, bilateral relations between Croatia and Montenegro have been positive and based on their common desire to join NATO and the EU, and later, the former's ability and willingness to help the latter.

Croatia's relationship with Serbia is much more complex than the one with Montenegro and much more troubled by bilateral disputes than the one with Bosnia and Herzegovina, even though the two countries transition from authoritarian, nationalist regimes to full parliamentary democracies in roughly the same period (Mladenov, 2014; Šelo Šabić, 2014). Demonstrative of the cool relations between the two countries is the fact that Mesic "built relations with all states of the former Yugoslavia during his mandate [but...] stood aloof from (re)building relations with Serbia was instrumental in Croatia's immediate recognition of the independence of Kosovo" (Šelo Šabić, 2014, p. 76), which antagonized relations with Serbia and commenced an ice age with Serbia which would remain frozen until Josipović's election to the presidency and subsequent state visit of Croatian prime minister Zoran Milanović to Belgrade in 2013 (Šelo Šabić, 2014). The 'ice age' in the two countries bilateral relations were characterized by, besides Croatia's recognition of Kosovo's independence, “the refugee issue, the issue of their property, housing rights, the postwar missing persons, war crime trials, and mutual suits before the International Court of Justice, pensions, company assets and disputes over succession after the breakup of Yugoslavia" (Rešić, 2013, p. 94). Despite further similarities between Croatia and Serbia in their endeavors to join the European Union and formal prioritization of EU membership (and membership in NATO, in the case of Croatia, and relations with larger countries, in the case of Serbia) over regional policies, they "rarely cooperate and see each other as rivals... [and] behave more as competitors than as partners" (Mladenov, 2014, p. 162).

Traditional thought's consensus regarding Croatian foreign policy toward its eastern neighbors are three-fold: Croatia has significant ties with ethnic Croats in Bosnia and Herzegovina through whom it can (and has) exert significant influence over Bosnian and Herzegovinian domestic politics; although Croatia and its eastern neighbors share many of the same foreign policy goals, cooperation has only been forthcoming with Montenegro; and the dynamic and quality, as well as depth and breadth, of relations between Croatia and its eastern neighbors, is largely based on the leader's personality and policy preferences, as opposed to rational or bureaucratic models. 


\section{PROJECTIONS OF AND OPPORTUNITIES FOR CROATIA'S FOREIGN POLICY}

Although the literature is lacking academic work on Croatia's foreign policy after its entrance into the European Union, several contributions deal with Croatia's foreign policy after its accession into the European Union in a predictive fashion, namely those by Jakovina (2010), Jović (2011), and Šelo Šabić (2013) ${ }^{7}$ while these authors provide an overview of some already adopted policies that are likely to remain after Croatia's entrance into the European Union. Jović and Šelo Šabić juxtapose Croatian foreign policy options to Christopher Hill's typology of states, concluding that Croatia is seeking and will continue to seek small power status by advocating for the accession of neighboring states into the European Union and assisting them based on its own experiences; relatedly, Jović discusses two differing foreign policy options toward the region, depending on the state's ideological convictions and Šelo Šabić proposes a sound, albeit elitist argument, as to why Croatia benefits from pursuing further EU enlargement; and Jakovina focuses foreign economic relations and potential handicaps to Croatia's foreign policy ambitions, which Jović also briefly discusses.

"Croatia through its membership in the EU will likely want to become a small power, rather than remain a small state" (Jović, 2011, p. 15), which is defined by its ability to disproportionately influence international politics. Jović postulates that the most realistic foreign policy option for Croatia is to find a niche and excel in it: "of the possible fields under consideration for such a specialization are regional cooperation, Mediterranean cooperation, cooperation with post-conflict states, and even cooperation with countries with a similar transition from one political, economic, and state system into another" "Jović, 2011, p. 18). Šelo Šabić builds on that argument, identifying regional cooperation as the most likely and most developed of the several niches Jović listed. "It is expected that Croatia and Croatia promises to, transfer the experience acquired in the negotiations process to candidates and potential candidates in the region" (Šelo Šabić, 2013, p. 15), which was confirmed by the Croatian government and the Croatian parliament (Šelo Šabić, 2013, pp. 17-8; Šelo Šabić, 2014, p. 84). She provides evidence of that foreign policy orientation through both discursive and nondiscursive action: the Croatian parliament adopted in 2011 a declaration which states that Croatia will "strongly advocate continuing the enlargement process and that open bilateral issues 'may not slow down candidates' accession into the European Union'” (Šelo Šabić, 2013, p. 17); the Croatian government adopted an official position that Croatia should be "a connection between the region and the EU" to be most familiar with the situation in the region and, due to its specialized knowledge, be in a special position to influence decision-making; and the founding of the Advisory Committee for Transitional Process and a related Center of Excellence in order "to transfer the knowledge gained through accession to the EU and NATO to the potential new members of both organizations, mainly those in the region of the Western Balkans" (Šelo Šabič, 2014, p. 86). As Jakovina (2010) notes, Croatia severed links with states with whom Yugoslavia had enjoyed friendly relations, thereby isolating itself and rendering its

\footnotetext{
${ }^{7}$ Of the aforementioned authors, only Jović explicity makes recommendations for future policy toward the region and even considers two competing foreign policy outlooks while Jakovića and Šelo Šabić address the future of Croatian foreign policy by identifying issues and implying its inverse ought to be adopted as official policy but without stating how to do so.
} 
remaining territory of action the West and, following rapprochement following Tuđman's death, its eastern neighbors. Therefore, Jović's and Šelo Šabić's argument that Croatia found and is developing its foreign policy niche in its region is correct by there being no other competitors.

Jović (2011) discusses the prospective difference between Croatian conservatives and liberals in terms of their policy preferences toward further EU enlargement and recommends liberals' policy preference by critiquing conservatives' policy preference, while Šelo Šabić (2014) disregards the potential dispute, probably assuming that a wide consensus for a single foreign policy will be built as it was in the past, and explains the rationale behind adopting a policy toward EU enlargement that Jović identifies as 'liberal'. The question of "does [Croatia] support further enlargement, toward which countries, and under which conditions" (Jović, 2011, p. 27) is, in a wider context, a question dependent on Croatia's internal ideological preferences: conservative ideological preferences will tend to "expect from EU enlargement an increase of security and stability... [and what consequences will it have on] Croatia's national identity, as well as the identity of Europe itself" (ibid.) while liberal or social democratic ideological preferences will tend to view EU enlargement as "an instrument of achieving greater justice and equality in the European, as well as the national, and partly the global framework" (ibid.). Although Jović posits that a wide and permanent consensus on Croatian foreign policy is hard to achieve since foreign policy is just another public policy which is subject to change, he cautions that "Croatia must be very careful to not endanger its position within the Union with a policy of unilateralism" (Jović, 2011, p. 33), which the conservatives are likely to advocate as a mechanism to solve regional disputes and further national interests. The liberals or social democrats, on the other hand, are likely to "advocate harmonizing [foreign policy] with European partners to make the Union stronger" (ibid.). Through his textual treatment of probable conservative and liberal or social democratic policies ${ }^{8}$, Jović demonstrates his preference and recommendation that the latter be the official policy and, if possible, both major parties' policy preferences. Šelo Šabić, with ostensibly similar ideological preferences as Jović but without addressing a potential divide in domestic actors' foreign policy preferences, notes that a prolonged period in which the rest of the Western Balkans doesn't enter the European Union would leave Croatia as the external border thereof and would "inevitably impact the redefining [Croatia's] national identity and strengthening of the consciousness of the differences that divide us instead of the similarities that connect us" (Šelo Šabić, 2013, p. 18). Both, therefore, conclude that advocating further enlargement and using its greater experience and skills in the integration process to assist other candidates and potential candidates on their journey to the European Union would be beneficial to Croatia and, explicitly or implicitly, dismiss opposing, i.e. conservative, views.

Jakovina agrees with Jović's argument that Croatia's foreign policy is decided by and reflects Croatia's internal dynamics but argues that the result of that was isolation from the non-Western

\footnotetext{
${ }^{8}$ For example, he describes probable conservative policies as "policies of conflict" and liberal or social democratic policies as "policies of compromise" and labeling conservative policies as "unilateral" and liberal or social democratic ones as "European," with the positive imagery invoked by the aforementioned concepts belonging to the ones associated liberal policies.
} 
world due to Croatia's "rejection of everything former, even that which was good, if it was connected to, for example, Yugoslavia" (Jakovina, 2010, p. 87) and subsequent lack of possibilities to find a niche, except in the European Union and its immediate neighborhood. Thus, by process of elimination, the logical inference is that Croatia will either remain a small state or find its niche in regional cooperation to become a small power. Jakovina, however, posits that such isolation isn't eternal and can be rectified, at least partly due to Yugoslavia's good relations with many states, and that Euro-centrism is inadequate as a niche Thus, he rhetorically poses the questions "can one of Croatia's specializations be better familiarity distant places, from Afghanistan to Africa? Can it be Croatia's niche and Croatian harbors the place of loading of their goods for Europe and vice-versa?" (Jakovina, 2010, p. 93) with the clear implication that one niche is inadequate for Croatia and that Croatia can and should have multiple niches, one of which should be developed relations and understanding of distant states. He identifies an obstacle to specializing in that niche: Croatia doesn't have experts for Bosnia and Herzegovina and Serbia, where it is expected to excel, and Croatian foreign policy repeatedly failed in the region or failed to capitalize on opportunities in the region. As a third foreign policy strategy that was lost since Croatian independence, he identifies the university system in Croatia. It used to educate both Croatians well and foreigners, some of which returned to their countries of origin to be parliamentarians, government officials, and mayors. "Those kinds of people, frequently more so than successful Croatians, are the real bridges between countries" (Jakovina, 2010, p. 96). He emphasizes the economic question, noting that "we'll export after we become a member of the Union" (ibid.) and identifies the aforementioned group of people and national minorities as especially key in assisting the continued or further export of goods. Although Jakovina doesn't provide policy recommendations, he identifies several areas of policy in which Croatia could and should improve to become a small power (without explicitly stating that, or anything else, as the purpose) and, therefore implicitly, provides policy recommendations in the form of policy outcomes.

The literature doesn't yet cover Croatia's foreign policy after accession into the European Union but three major authors pose several policy recommendations for Croatian foreign policy after 2013: identify and excel in a niche to become a small power; due to ability, expectations, and proximity, Croatia's niche should be contributing to and supporting the EU integration of the Western Balkans region; and Croatia should cultivate ties with non-EU states due to the possibilities inherent in such endeavors through aiming to educate foreigners that are likely to be influential in their respective societies and capitalizing on Yugoslavia's legacy in those countries to create economic links.

\section{CONCLUSION}

Although the literature on Croatian foreign policy is extensive, both analytically and prospectively and descriptively and normatively, most of it focuses on Croatia's foreign policy through a rather traditional lens. There is a noticeable lack of constructivist and especially discursive studies analyzing Croatian foreign policy, generally and specifically toward its eastern neighbors. The latter is even more noticeable than the former. In addition, there are no 
studies conducted on Croatia's foreign policy and its cohabitation system. Therefore, there is significant academic value in conducting a less traditional discourse analysis of Croatia's foreign policy towards Bosnia and Herzegovina, Montenegro, and Serbia, as its newfound niche foreign policy, and taking into consideration Croatia's cohabitation system of government and the shift of power that has taken place since 2000.Although the literature on Croatian foreign policy is extensive, both analytically and prospectively and descriptively and normatively, most of it focuses on Croatia's foreign policy through a rather traditional lens. There is a noticeable lack of constructivist and especially discursive studies analyzing Croatian foreign policy, generally and specifically toward its eastern neighbors. The latter is even more noticeable than the former. In addition, there are no studies conducted on Croatia's foreign policy and its cohabitation system. Therefore, there is significant academic value in conducting a less traditional discourse analysis of Croatia's foreign policy towards Bosnia and Herzegovina, Montenegro, and Serbia, as its newfound niche foreign policy, and taking into consideration Croatia's cohabitation system of government and the shift of power that has taken place since 2000 .

\section{REFERENCES}

Džankić, J. (2012). From Creeping to Sprinting: The Foreign Policy of Montenegro. In S. Keil \& B. Stahl, The Foreign Policies of Post-Yugoslav States: From Yugoslavia to Europe (pp. 173-197). London: Palgrave Macmillan.

Felbauer, E., \& Jureković, P. (2014). Croatian Membership in the EU - Implications for the Western Balkans. In 15th and 27th Workshop of the PfP Consortium Study Group Regional Stability in southeast Europe (pp. 19-36). Vienna: Republic of Austria / Federal Ministry of Defence and Sports.

Grubiš, D. (2000). The Zagreb Summit and Croatian Foreign Policy. Croatian International Relations Review, 117-121.

Huskić, A. (2014). Complex System, Complex Foreign Policy: The Foreign Policy of Bosnia and Herzegovina. In S. Keil \& B. Stahl, The Foreign Policies of Post-Yugoslav States: From Yugoslavia to Europe (pp. 122-143). London: Palgrave Macmillan.

Jakovina, T. (2010). Hrvatska vanjska politika: Što smo bili, što jesmo, što želimo i što možemo biti?. In N. Budak \& V. Katunarić, Hrvatski nacionalni identitet u globalizirajućem svijetu (pp. 83-101). Zagreb: Centar za demokraciju i pravo Miko Tripalo.

Johnson, A. (2014). The Balans is our Neighborhood, Europe is our Destiny: Croatia's Attempt to Build Regional Relations in Hope of EU Membership (Bachelor). University of North Carolina. 
Jović, D. (2011). Hrvatska vanjska politika pred izazovima članstva u Europskoj Uniji. Politička Misao, 48(2), 7-36.

Jović, D. Palubna diplomacija i funkcionalna suradnja: hrvatsko-srpski bilateralni odnosi na početku mandata Ive Josipovića, 1-27.

Mladenovi, M. (2014). An Orpheus Syndrome? Serbian Foreign Policy After the Dissolution of Yugoslavia. In S. Keil \& B. Stahl, The Foreign Policies of Post-Yugoslav States: From Yugoslavia to Europe (pp. 147-172). London: Palgrade Macmillan.

Rešić, A. (2013). Croatian Strategy of Multilateralism: Investment in Becoming a Regional Leader towards the EU. Međunarodne Studije, 14(1), 87-101.

Šelo Šabić, S. (2013). Politika Hrvatske prema susjednim državama. Političke Analize, 14, 1520.

Šelo Šabić, S. (2014). Croatia's Fast-Forward Foreign Policy: From Yugoslavia to the EU. In S. Kiel \& B. Stahl, The Foreign Policies of Post-Yugoslav States: From Yugoslavia to Europe (pp. 69-93). London: Palgrave Macmillan.

Vukičević, B. (2017). Foreign Relations of Post-Independence Montenegro: A Change of Direction. Lithuanian Foreign Policy Review, 36, 107-135. 